\title{
DEBUTS
}

Claudia S. Quiñones Vilát

claudia.quinones.vila@gmail.com

Amineddoleh \& Associates LLC

43 West 43rd Street, Suite 171

New York, NY 10036, United States

\section{Cultural Heritage in the European Union: An Outsider's Perspective}

\begin{abstract}
Cultural heritage protection has risen to the forefront of EU politics and policies in recent years, as a response to its intrinsic value and social benefits. Nonetheless, each Member State has its own legal definitions and approaches to cultural heritage protection, corresponding to their respective historical, social, political, and economic contexts. The principle of subsidiarity also entails a substantial amount of delegation, which means that bureaucratic obstacles are added to functional ones (lack of funds, geographical divides, etc.), which can inhibit the free exchange of information and communication. Accordingly, heritage protection is uneven across the EU not only due to varying conceptions of what constitutes heritage, but also as to who is considered an appropriate caretaker or stakeholder, and to what extent they should be involved. The present article provides an overview of the ongoing challenges to cultural heritage preservation and presents recommendations for improvement, from a non-EU citizen's perspective. It focuses on two countries - the UK and Italy - as practical examples, given their
\end{abstract}

\footnotetext{
*laudia S. Quiñones Vilá is a licensed attorney in New York and Puerto Rico with experience in civil international law and an interest in the art market, illicit trafficking of cultural objects, sustainable development, urban law, and public policy. She currently works at Amineddoleh \& Associates, a leading NYC legal firm dealing in art and cultural heritage disputes for high-profile clients, including the Cultural Ministry of Greece. In 2018, she completed an internship at UNIDROIT in Rome focusing on cultural property, specifically the 1995 UNIDROIT Convention's applicability to private art collections in the US and Latin America. In 2019, she received honours for her master's thesis on cultural heritage legislation and policy in the EU as part of the EUPADRAMA/LLM program hosted by LUISS Guido Carli University (Rome), the Universidad Complutense (Madrid), and the University of London. She is also a member of The International Art Market Studies Association (TIAMSA) Legal Group and a contributor to their blog, as well as of the International Law Association (ILA) and the Lawyers' Committee for Cultural Heritage Preservation (LCCHP).
} 


\section{DEBUTS}

Claudia S. Quiñones Vilá

wealth of cultural heritage but different approaches to protecting and managing the same. By investigating the results of these approaches from a critical and outside perspective, it is possible to glean what the underlying problems are and how they should be addressed for greater effectiveness.

Keywords: cultural heritage, public policy, European Union, Italy, United Kingdom, private stakeholders, cultural property, diversity, cultural property legislation

\section{Introduction}

To an outsider, the policies of the European Union (EU) can appear complex and confusing, and the area of cultural heritage is no exception. Due to the principle of subsidiarity, there are certain areas in which the EU is bound not to intervene unless specific circumstances arise. ${ }^{1}$ With 28 Member States and a multiplicity of regions, provinces, and municipalities, there is a formidable amount of cultural diversity present in the Union. Thus, EU legislation and policy are aimed at bolstering national legislation on these matters and creating a harmonious means of exchange. In practice, however, the free flow of information and availability of resources do not guarantee that States will adopt innovative methods to increase the return value of their cultural heritage. In particular, sociopolitical conceptions of governmental intervention in cultural matters are significant; when heritage is seen as primarily the State's responsibility, a lack of public funds can prove disastrous for its upkeep. This issue becomes even more pressing in the age of austerity measures and post economic recession, as tourism and urban migration continue to soar.

Nonetheless, it is possible for States to take advantage of the situation by refocusing their conceptions of cultural heritage away from traditional roles that no longer serve contemporary expectations. The aim of this article is to put forth suggestions to increase the effectiveness of cultural heritage legislation and policy in the EU. To do so, I examine recent developments in Italy and the United Kingdom (UK), which offer both counterpoints to each other as well as fertile ground for discussion. Prior to this analysis, it is necessary to examine the available legal and policy frameworks within the $\mathrm{EU}$, which serve as a preliminary mise-en-scène according to the significance of cultural heritage for supranational bodies. The subsequent recommendations are a product of critical analysis, based on an outsider's perspective.

1 Article 5(3) of the Treaty on European Union (consolidated version), OJ C 326, 26.10.2012, p. 13; and Protocol No. 2 to the Treaty on the Functioning of the European Union on the application of the principles of subsidiarity and proportionality (consolidated version), OJ C 326, 26.10.2012, p. 206. 


\section{Cultural Heritage in the EU Legal Framework}

Nowadays it is commonly accepted that cultural heritage is a multifaceted and dynamic subject of tremendous importance for modern democratic societies, in addition to its economic benefits. ${ }^{2}$ Access to, participation in, and respect for cultural heritage are placed within the scope of human rights in the EU legal framework, ${ }^{3}$ as the EU's status as a "soft power" depends on its commitment to shared values and cultural richness, which is deemed as "an important asset in an immaterial and knowledge-based world". 4 The legal bases for EU participation in cultural matters are Article 3 of the Treaty on European Union (TEU) and Articles 6 and 167 of the Treaty on the Functioning of the European Union (TFEU). ${ }^{5}$ Article 3(3) TEU tasks the EU government with respecting its rich cultural diversity, and ensuring that European cultural heritage is safeguarded and enhanced. Article 6 TFEU provides that the Union shall have competence to "support, coordinate or supplement the actions of the Member States", including in the area of culture.

Article 167 TFEU states that

The Community shall contribute to the flowering of the cultures of the Member States, while respecting their national and regional diversity and at the same time bringing the common heritage to the fore. Action by the Community shall be aimed at encouraging cooperation between Member States and, if necessary, supporting and supplementing their action.

The treaties make clear that respecting and promoting cultural diversity is of paramount importance for the EU at both the national and supranational levels. EU governing bodies have continued to support this mandate by issuing various legislative and policy texts; 6 the most relevant of which are discussed below.

2 J. Hosagrahar et al., Heritage, the UN Sustainable Development Goals, and the New Urban Agenda, "ICOMOS Concept Note on Housing and Sustainable Urban Development (HABITAT III)", 15 February 2016, p. 9, https://www.usicomos.org/mainsite/wp-content/uploads/2016/05/Final-Concept-Note.pdf [accessed: 26.04.2019].

3 S. Pinton, The Faro Convention, the Legal European Environment and the Challenge of Commons in Cultural Heritage, in: S. Pinton, L. Zagato (eds.), Cultural Heritage: Scenarios 2015-2017, Ca' Foscari - Digital Publishing, Venice 2017, p. 317.

4 Commission of the European Communities, Communication from the Commission to the European Parliament, the Council, the European Economic and Social Committee and the Committee of the Regions on a European agenda for culture in a globalizing world, 10 May 2007, COM (2007) 242 final, p. 3.

5 (Consolidated version), OJ C 326, 26.10.2012, p. 47; also see: European Commission, Joint Communication to the European Parliament and the Council: Towards an EU strategy for international cultural relations, 8 June 2016, JOIN(2016) 29 final, p. 3.

6 M. Pasikowska-Schnass, Cultural Heritage in EU Policies, European Parliamentary Research Service, June 2018, http://www.europarl.europa.eu/RegData/etudes/BRIE/2018/621876/EPRS_BRI(2018)621876_ EN.pdf [accessed: 24.04.2019]. 


\section{DEBUTS}

Claudia S. Quiñones Vilá

In 2007, the European Commission issued a Communication on a European agenda for culture in a globalizing world, 7 proposing that a joint work plan in the area of culture would enable stakeholders to streamline their goals and determine the appropriate measures to meet these objectives, such as the Open Method of Coordination (OMC). The $\mathrm{OMC}$ is a non-binding, intergovernmental mechanism which allows Member States to retain their competences while allowing them to engage in beneficial policy exchanges by agreeing on common objectives, following up on progress, and exchanging best practices and relevant data between themselves and the EU. ${ }^{8}$ Due to its non-mandatory nature, however, its effectiveness depends on both governments' willingness to participate as well as the amount and types of information submitted.

Recognizing the need for further development, the Council issued Conclusions on Cultural Governance in 2012, emphasizing the importance of a more open, participatory, informed, effective, and transparent cultural governance and encouraging the Member States to promote participation in their definition of cultural policies. ${ }^{9}$ In 2014, the Council of the EU adopted Conclusions on cultural heritage as a strategic resource for a sustainable Europe, ${ }^{10}$ while the EU Commission published a complementary communication titled Towards an integrated approach to cultural heritage for Europe. ${ }^{11}$ The resulting 2015-2018 Work Plan for Culture set forth the following main priorities: 1) Accessible and inclusive culture; 2) Cultural heritage; 3) Cultural and creative sectors, creative economy, and innovation; and 4) Promotion of cultural diversity, culture in EU external relations, and mobility. ${ }^{12}$ Repeated mentions of synergy and cross-sectoral cooperation provide insight into the Union's priorities: it asks the Member States to consider the results of the Work Plan when developing policy at the national level and taking culture into account when formulating, implementing, and evaluating policies and actions in other policy fields. ${ }^{13}$

The Work Plan corresponds to the Commission's statement that "it is in the shared interest of all Member States to harness the full potential of education and culture as drivers for jobs, economic growth, social fairness, active citizenship as well as a means to experience European identity in all its diversity" and to "offer

$7 \operatorname{COM}(2007) 242$ final.

$8 \operatorname{COM}(2007) 242$ final, p. 12.

9 OJ C 393, 19.12.2012, p. 8.

10 OJ C 183, 14.06.2014, p. 36.

1122 July 2014, COM(2014) 477 final.

12 European Commission, Strategic framework - European Agenda for Culture, https://ec.europa.eu/culture/ policy/strategic-framework_en [accessed: 26.04.2019].

13 Council of the European Union, Conclusions of the Council and of the Representatives of the Governments of the Member States, meeting within the Council, on a Work Plan for Culture (2015-2018), OJ C 463 , 23.12.2014, pp. 4-5; also see: European Commission, Mapping of Cultural Heritage Actions in European Union Policies, Programmes and Activities, 2014 (latest update: August 2017), http://ec.europa.eu/assets/eac/culture/library/reports/2014-heritage-mapping_en.pdf [accessed: 26.04.2019]. 
a vision of an attractive European Union". ${ }^{14}$ As hubs for innovation, cities draw financial gains by attracting creative enterprises and providing an entry point for citizens to the job market, notably in the youth sector. ${ }^{15}$ While the world recovers from the economic recession, alternative and creative strategies are gaining traction in order to market the EU and its Member States more favorably as tourist and employment destinations. A Work Plan for Culture 2019-2022 was established in November 2018, to continue developing the goals of the previous Work Plan through a horizontal and holistic approach to legislation, financing, and cross-sectoral cooperation. ${ }^{16}$

Pursuant to the Rome Declaration of $2017,{ }^{17}$ the 27 Member States, the European Council, European Parliament, and European Commission all recognized that the EU is "facing unprecedented challenges, both global and domestic" and reaffirmed their commitment to "make the European Union stronger and more resilient, through even greater unity and solidarity amongst us and the respect of common rules". ${ }^{18}$ By focusing on cultural heritage, the EU can be "safe and secure, prosperous, competitive, sustainable and socially responsible, and with the will and capacity of playing a key role in the world and of shaping globalization". ${ }^{19}$ This also led to the creation of a new cultural agenda to tackle social, political, and economic problems.

The strategic objectives of the 2018 New European Agenda for Culture are divided into three sections, or dimensions: social, economic, and external. Within the social dimension, the Commission recognizes how cultural participation brings people together, constitutes a transformative force for community regeneration, and improves citizens' health and well-being. "Cultural capability", i.e. the capacity to work with a wide range of cultural activities and opportunities, is the guiding principle and the Commission promises under the Creative Europe program to launch a project on "Cultural creative spaces and cities" to promote cultural participation as well as social and urban regeneration. ${ }^{20}$ Here the social aspect overlaps with the economic one, as urban regeneration fosters favorable ecosystems

14 European Commission, Communication from the Commission to the European Parliament, the European Council, the Council, the European Economic and Social Committee and the Committee of the Regions: A New European Agenda for Culture, 22 May 2018, COM(2018) 267 final ("2018 Agenda for Culture"), p. 1.

15 Ibidem, p. 5.

16 Council of the European Union, Council conclusions of 6 December on the Work Plan for Culture 2019-2022, OJ C 460/10, 21.12.2018, p. 12.

17 Council of the European Union, The Rome Declaration: Declaration of the leaders of 27 member states and of the European Council, the European Parliament and the European Commission, Statements and Remarks 149/17, 25 March 2017, https://www.consilium.europa.eu/en/press/press-releases/2017/03/25/ rome-declaration/pdf [accessed: 26.04 .2019 ].

18 Ibidem, Preamble.

19 Ibidem.

202018 Agenda for Culture, op. cit., pp. 2-3. 


\section{DEBUTS}

Claudia S. Quiñones Vilá

for cultural and creative industries, which in turn generate financial gains. ${ }^{21} \mathrm{~A}$ key feature is the close relationship with existing programs in the economic sector, such as agriculture, education, rural and regional development, environment, and tourism. ${ }^{22}$ Stakeholders now understand that policy aspects in these areas are interrelated and require an expansive view, cooperation with Union as well as Member State authorities, and a holistic approach in order to reach their full potential. ${ }^{23}$ Finally, the Agenda's external dimension aims to strengthen international cultural relations through the promotion of culture and intercultural dialogue for peaceful inter-community relations, and the reinforcement of cooperation in the field of cultural heritage. ${ }^{24}$ The European Year of Cultural Heritage, celebrated in 2018, was a tangible representation of the EU government's preoccupation with "promoting the role of European cultural heritage as a pivotal component of cultural diversity and intercultural dialogue". ${ }^{25}$ However, cultural policies also have internal repercussions, as heritage can play a role in justifying political conflicts. ${ }^{26}$ But at the same time cultural heritage can also serve as a means of course-correction, by making the "other" more familiar and, in turn, less frightening. Commonality, rather than differences, unites countries - although Member States will always resist attempts to dilute their cultural identities.

\section{National Cultural Heritage Policies and Development}

While there are thus many statutory and policy frameworks in place across the EU supporting cultural heritage protection, the difficulty in fully harnessing its benefits often comes down to a lack of uniformity in its characterization. ${ }^{27}$ While the EU must respect Member States' own definitions of cultural heritage and the relevant means of protection, it has a vested interest in encouraging cooperation through a shared agenda. ${ }^{28}$ The tension between the need for uniform policies to facilitate supranational cultural heritage management and the significance of using local con-

\footnotetext{
21 Ibidem, p. 4.
}

22 Decision (EU) 2017/864 of the European Parliament and of the Council of 17 May 2017 on a European Year of Cultural Heritage (2018), OJ L 131, 20.05.2017, paras. 13 and 23.

232018 Agenda for Culture, op. cit., p. 10.

24 Ibidem, p. 6; also see: European Commission, Communication from the Commission to the European Parliament, the Council, the European Economic and Social Committee and the Committee of the Regions on a European agenda for culture in a globalizing world, 10 May 2007, COM(2007) 242 final.

25 European Commission, Proposal for a Decision of the European Parliament and of the Council on a European Year of Cultural Heritage, 30 August 2016, COM(2016) 543 final, 2016/0259 (COD), p. 2.

26 V. Kisić, Governing Heritage Dissonance. Promises and Realities of Selected Cultural Policies, European Cultural Foundation, Amsterdam 2016, p. 33, https://www.europanostra.org/wp-content/uploads/2017/01/ Governing_Heritage_Dissonance.pdf [accessed: 26.04.2019].

27 Y. Ahmad, The Scope and Definitions of Heritage: From Tangible to Intangible, "International Journal of Heritage Studies" 2006, Vol. 12(3), p. 296-297.

28 Towards an EU strategy..., p. 3. 
texts to create effective legislation is constantly present and prevents simple solutions. Furthermore, the increased role of the private sector in heritage protection "is a clear signal that European citizens want to play a greater role in public life," adding a new dimension to national administrative, legislative, and financial regulations. ${ }^{29}$

Each State has its own perception of what its cultural heritage is, how it should be protected, and what role the government should occupy in this process. In order for States to engage with the applicable EU rules and regulations in this area, the first step is to define cultural heritage and delineate the place it occupies in the national legal order. As a frame of reference, cultural heritage is defined by the Faro Convention ${ }^{30}$ rather expansively, as: "a group of resources inherited from the past which people identify, independently of ownership, as a reflection and expression of their constantly evolving values, beliefs, knowledge and traditions. It includes all aspects of the environment resulting from the interaction between people and places through time". ${ }^{31}$ This definition covers both the tangible and intangible forms of heritage, such as languages and local customs. ${ }^{32}$ However, States' individual approaches vary considerably.

\section{Italy}

The development of heritage protection in Italy's public sector owes much to the legacy of fascism. Legislation enacted during this period was remarkably forward-thinking in the field of cultural protection, as Italy was one of the first countries to establish a ministry specifically dedicated to the management of the cultural sector. ${ }^{33}$ Italy's history is a "political mosaic" - where the nation has inherited, but not created, disparate cultural property, which makes it impossible to amalgamate the various regional identities into a cohesive and "profound national identity". ${ }^{34}$ Nonetheless, populist party The Five Star Movement (5SM) wants to reclaim the country's former glory and shed the image of poverty by utilizing cultural heritage as a tangible representation of a singular Italian identity, demonstrating how heritage can be used as a propaganda tool. ${ }^{35}$

29 European Parliament, Committee on Culture, Youth, Education, the Media and Sport, Report on cultural cooperation in the European Union (2000/2323(INI)), 16 July 2001, A5-0281/2001, p. 13.

30 Council of Europe Framework Convention on the Value of Cultural Heritage for Society, 27 October 2005, CETS 199.

31 Article 2(a).

32 Also see: Council conclusions of 21 May 2014, op. cit.

33 C. Bodo, S. Bodo, Italy. Historical Perspective: Cultural Policies and Instruments, "Compendium: Cultural Policies and Trends", 5 July 2016, p. 1, https://www.culturalpolicies.net/web/italy.php [accessed: 26.04.2019].

34 E. Moustaira, Art Collections, Private and Public: A Comparative Legal Study, Springer, Cham 2015, p. 62.

35 A. Woodhouse, J. Politi, Populist Five Star Movement Secures $32 \%$ of Vote in Italian Election, "Financial Times", 5 March 2018, https://www.ft.com/content/ecd89a82-2045-11e8-a895-1ba1f72c2c11 [accessed: 26.04.2019]. 


\section{DEBUTS}

Claudia S. Quiñones Vilá

Irrespective of political parties, Italy has a long history of zealous heritage protection. The Italian Constitution sets forth in Article 9 the government's affirmative obligations to protect and enhance the nation's cultural heritage in order to preserve the memory of the national community and its territory and to promote the development of culture. ${ }^{36}$ While the protection of the environment and cultural heritage is an exclusive competence of the State, concurring legislation applies to the enhancement of cultural properties, including the promotion and organization of cultural activities ${ }^{37}$ In addition to the Constitution, the Landscape and Cultural Heritage $\mathrm{Code}^{38}$ is the main legal instrument governing cultural heritage and property. Cultural heritage here consists of "cultural property and landscape assets". ${ }^{39}$ Cultural property is widely defined as not only that which possesses artistic, historical, archaeological, or bibliographical interest, but also "any other thing identified by law or in accordance with the law as testifying to the values of civilisation". ${ }^{40}$ This includes art collections, archives, and artefacts belonging to the State, regions, public bodies, and private non-profit associations. ${ }^{41}$ The Code further imposes a duty on private owners, possessors, or holders of cultural heritage to ensure its conservation. ${ }^{42}$ Private property is subject to State ownership subsequent to an official declaration of cultural interest. ${ }^{43}$ Fifteen ordinary regions have concurrent legislative powers in this field, while five autonomous regions have greater competences. ${ }^{44}$ Provinces do not play a large role, although municipal departments for culture are crucial for the direct and indirect management of cultural institutions and events. ${ }^{45}$

The State exercises its constitutional duties to protect and conserve national heritage for the purposes of public enjoyment through the Ministry for Cultural Heritage and Activities (MiBAC). ${ }^{46}$ Regions and other territorial bodies are bound to cooperate with the Ministry's directives, although the MiBAC may confer the

36 Constitution of the Italian Republic, https://www.senato.it/documenti/repository/istituzione/costituzione_inglese.pdf [accessed: 26.04.2019]. See also, Italian Landscape and Cultural Heritage Code, Articles 1(1), 1(2).

37 Article 117 of the Italian Constitution.

38 Codice dei beni culturali e del paesaggio, 22 January 2004, Gazzetta Ufficiale Serie Generale No. 45 ("Heritage Code").

39 Article 2(1).

40 Article 2(2).

41 Article 10.

42 Article 1(5).

43 Article 13.

44 Council of Europe, Compendium Short Profile: Italy, https://www.culturalpolicies.net/web/files/308/en/ Italy.pdf [accessed: 26.04.2019]; Presidential Decree 616 of 24 July 1977, Gazzetta Ufficiale Serie Generale No. 234; Constitutional Law 3 of 18 October 2001, Gazzetta Ufficiale Serie Generale No. 248.

45 Council of Europe, Compendium..., p. 4.

46 Ministero dei Beni e delle Attività Culturali. Articles 3(1), 4(1) of the Heritage Code. 
exercise of certain functions upon the regions, which retain administrative functions and the power to make decisions regarding cultural heritage not belonging to the State. ${ }^{47}$ One must keep in mind that the modern State of Italy is relatively young, with only 150 years of political unity; thus the desire to centralize the governance of public cultural patrimony is a natural consequence of this comparatively brief shared history. For instance, Article 150(4) of Law Decree 112/1998 transferred the governance of State-run museums to regional and local entities. ${ }^{48}$ However, in practice, the organizational, financial, and accounting matters remain under the MiBAC's purview. This incomplete transfer is due to "a lack of a real tradition of national unity", where regional/local identities remain stronger than the national/Italian one. As a result, there is an "unwillingness to have central, national, care and governance of the national institutions".49

Private parties have also been brought in to address gaps in oversight, with mixed results. ${ }^{50}$ The Financial Act of $2002^{51}$ introduced controversial legislation allowing the sale of public property which has been assigned a cultural or historical value to private owners. The Ministry of Economic Affairs was in charge of compiling a list of alienable assets and was required to verify with the MiBAC prior to engaging in such transactions. In practice, however, the situation is not so straightforward; there is no comprehensive list of cultural property or clear requirements for the preservation of the property post-purchase, and the recommendations of municipalities and regions are often bypassed. Additionally, a lack of institutional cooperation and transparency has led to the sale of these properties far below market price. This has led to a debate on privatization, compounded by Italy's astounding wealth of cultural heritage and its comparatively low GDP allocation to this area..$^{52}$ Other nations are also concerned, since they view this patrimony as world heritage..$^{53}$

Italy's lack of public funds is a serious matter for cultural heritage preservation. ${ }^{54}$ Consequently, the MiBAC has undergone significant internal reforms, abolishing its departments and reducing directorates in order to streamline its respon-

\footnotetext{
47 Articles 4(1), 5(2), 5(6) of the Heritage Code.

48 See also, E. Moustaira, op. cit., p. 61.

49 Ibidem, p. 62.

50 Ibidem, p. 63.

51 Law 112 of 15 June 2002, Gazzetta Ufficiale Serie Generale No. 139.

52 C. Ventura, G. Cassalia, L. Della Spina, New Models of Public-Private Partnership in Cultural Heritage Sector: Sponsorships between Models and Traps, "Procedia - Social and Behavioral Sciences" 2016, Vol. 223, p. 258.

53 R. Benedikter, Privatisation of Italian Cultural Heritage, "International Journal of Heritage Studies" 2004, Vol. 10(4), pp. 383-385.

54 Italy spends just $0.2 \%$ of its GDP on cultural matters, as opposed to other EU Member States (for example France spends 1\%). R. Scammell, Saving Italy's Cultural Heritage by Modern Means, "The Guardian", 19 March 2015, https://www.theguardian.com/world/2015/mar/19/saving-italys-cultural-heritage-bymodern-means [accessed: 26.04.2019].
} 


\section{DEBUTS}

Claudia S. Quiñones Vilá

sibilities. ${ }^{55}$ In 2014, Dario Franceschini, the newly appointed Head of the MiBAC, implemented an innovative strategy to raise funds from within the private sector to assist in heritage maintenance and combat the "absolute lack of integration" between cultural preservation and tourism generation. Moreover, he targeted the bureaucratic red tape plaguing the national civil services. ${ }^{56}$ Crowdfunding, philanthropy, and tax breaks are the latest way to raise "cash for culture", although the MiBAC strongly prohibits personal branding when accepting donations. Additionally, Franceschini appointed new directors to 20 national museums, including the Uffizi Gallery in Florence, in order to create a broader cultural experience; ${ }^{57}$ in fact some of these directors are not even Italian. They have a new approach, aimed at attracting art lovers rather than solely focusing on the preservation of artworks. ${ }^{58}$

Italy has lagged behind when it comes to utilizing cultural heritage to its best advantage; in the sense that incoming funds gathered from millions of tourists have not been adequately funneled into conservation. ${ }^{59}$ Given that cultural tourism has become an important part of establishing national and regional legislation and identity politics across the globe, Italy has failed to adequately integrate this phenomenon with heritage management. ${ }^{60}$ Such "perverse carelessness" is a legacy of Berlusconi's decades in power and the overwhelming amount of cultural wealth across the country, leading to a cognitive dissonance between the presence of cultural objects and the need for conservation measures. ${ }^{61}$ On the other hand, Italian cultural heritage abroad has received great attention. Cooperation with the international community has been integral to the success of Italy's recovery of looted and illegally exported artifacts, pursuant to local legislation in conjunction with international agreements. ${ }^{62}$ In fact, the MiBAC leads a specialized branch of the po-

55 P. Forte, I nuovi musei statali: un primo passo nella giusta direzione, "Aedon" 2015, Vol. 1, http://www.aedon.mulino.it/archivio/2015/1/forte.htm [accessed: 24.04.2019].

56 A. Forbes, Italy Announces Sweeping Cultural Reforms, "Artnet News", 21 July 2014, https://news.artnet. com/art-world/italy-announces-sweeping-cultural-reforms-64457 [accessed: 26.04.2019].

57 R. Scammell, Saving Italy's Cultural Heritage...

58 R. Scammell, The New British Caretaker of Italian Culture, "The Observer", 26 June 2016, https://www. theguardian.com/culture/2016/jun/25/james-bradburne-british-museum-director-artistic-revolution-milan [accessed: 26.04.2019].

59 At one point, chunks of masonry were falling from the Colosseum, which is one of the most popular tourist attractions in Rome. See M. Day, Italy's Cultural Heritage at Risk Amid Neglect and Bad Management With Private Sponsors Brought in to Help Protect Iconic Landmarks, "The Independent", 17 May 2015, https:// www.independent.co.uk/news/world/europe/italys-cultural-heritage-at-risk-amid-neglect-and-bad-management-with-private-sponsors-brought-in-to-10256659.html [accessed: 26.04.2019].

60 J. Butcher, Cultural Politics, Cultural Policy and Cultural Tourism, in: M.K. Smith, M. Robinson (eds.), Cultural Tourism in a Changing World: Politics, Participation and (Re)presentation, Channel View Publications, Bristol 2006, p. 21-22.

61 Ibidem.

62 M. Frigo, Italy, in: J.A.R. Nafziger, R.K. Paterson (eds.), Handbook on the Law of Cultural Heritage and International Trade, Edward Elgar Publishing, Cheltenham 2014, pp. 235-251. See, e.g., Article 36 TFEU (circulation of national treasures within the internal market); Articles 64-bis, 65, 68, 74-78, 86 of the Herit- 
lice force tasked with tracking down objects and reducing thefts, which has resulted in a significant reduction of illegal activities in this area over the past decade. ${ }^{63}$

Currently, Italy's new government has initiated a "cultural heritage clampdown" after the success of many high-profile repatriations, including the introduction of stiffer penalties imposed on those who engage in cultural heritage crimes, seen as a "fundamental part of [Italian] identity" by the 5 SM nationalist party. ${ }^{64}$ Indeed, the present minister for cultural heritage, Alberto Bonisoli, announced the government's intention to ratify the 2017 Nicosia Convention, ${ }^{65}$ which establishes sanctions for cultural property crimes. ${ }^{66} 5 \mathrm{SM}$ also wants to increase public spending and renegotiate Italy's debt, pitting itself against the European Commission. ${ }^{67}$ The clash between national and EU policies is already apparent, as globalization and diversity have been pushed aside in favor of populism.

\section{The United Kingdom}

Unlike Italy, which is a source country, the UK is a market country for cultural objects. ${ }^{68}$ This classification has affected the development of heritage protection, as there is no single concept of national patrimony. Rather, legislation deals with cultural property as it relates to economic and real property principles. ${ }^{69}$ Since cultural objects are frequently sold to collectors and institutions in the UK, it has developed strict export criteria but is more lenient towards imports. These controls were developed to retain objects of particular importance to the country's cultural heritage, designed to "strike a balance between various interests, namely, the protection of the national heritage, the interests of sellers, and the need to safeguard

age Code; Convention on the Means of Prohibiting and Preventing the Illicit Import, Export and Transfer of Ownership of Cultural Property, 14 November 1970, 823 UNTS 231; UNIDROIT Convention on Stolen or Illegally Exported Cultural Objects, 24 June 1995, 34 ILM 1322; Law 213 of 7 June 1999, Gazzetta Ufficiale Serie Generale No. 153.

63 Comando dei Carabinieri per la Tutela del Patrimonio Culturale. In 2009, thefts of cultural objects were down by $14.5 \%$, while clandestine archaeological excavations decreased by $76 \%$. M. Frigo, Italy, p. 248 , citing Report of the Comando dei Carabinieri per la Tutela del Patrimonio Culturale of 13 January 2009.

64 A. Vogt, Italy's Populist Government Brings In New Laws to Crack Down on Artefact Trafficking Amidst Nationalist Swell, "The Telegraph", 4 November 2018, https://www.telegraph.co.uk/news/2018/11/04/italys-populist-government-brings-new-laws-crack-artefact-trafficking/ [accessed: 26.04.2019].

65 Council of Europe Convention on Offences relating to Cultural Property, 19 May 2017, CETS 221.

66 M. Wecker, Looted Vessels Returned at Event Marking 15 Years of US-Italy Art Crime Fighting Co-operation, "The Art Newspaper", 6 November 2018, https://www.theartnewspaper.com/news/looted-vessels-returned-at-event-marking-15-years-of-us-italy-art-crime-fighting-co-operation [accessed: 26.04.2019].

67 S. Amaro, Italy's Anti-establishment Government Hopes the Rules Change in Its Favor Next May, "CNBC", 9 October 2018, https://www.cnbc.com/2018/10/09/italys-populist-government-hopes-the-rules-changein-its-favor.html [accessed: 26.04.2019].

68 K. Chamberlain, K. Hausler, United Kingdom, in: J.A.R. Nafziger, R.K. Paterson (eds.), op. cit., p. 460.

69 B. Boesch, The Art Collecting Legal Handbook, Thomson Reuters, London 2013, p. 81. 


\section{DEBUTS}

Claudia S. Quiñones Vilá

the UK's reputation in the international art market"..$^{0}$ Various organizations provide financial assistance for cultural objects at risk of export, enabling museums and galleries to purchase items they would not otherwise be able to afford. ${ }^{71}$

Private parties in the UK play a significant role in cultural heritage protection and management, as there is a long-established tradition of philanthropy, including bequests and donations to public and private institutions. Any individual can set up a charitable foundation or a private museum dedicated to the holding, preservation, study, and promotion of cultural property. These can take the form of either companies or trusts, the latter of which are often used in common law. ${ }^{72}$ Furthermore, it must be noted that many of the UK's leading collections, both private and public, contain cultural objects from other countries. The most famous example is the Parthenon marbles currently located in the British Museum, although Greece has initiated legal action for their return. ${ }^{73}$ This raises moral and ethical questions as to what is considered significant cultural heritage for the UK, and how to justify an object's retention if it possesses historical significance but did not originate within the nation. ${ }^{74}$

The UK is also unique due to its legislative structure, which combines the constitutional principle of parliamentary sovereignty with three devolved legislative assemblies in Northern Ireland, Scotland, and Wales. Each region has the delegated authority to issue legislation and policy measures on areas affecting culture and tourism, although they are always subordinate to the Westminster Parliament. ${ }^{75}$ This has resulted in regional particularities that nonetheless adhere to a centralized structure. The centralized government operates through the Department for Digital, Culture, Media \& Sport (DCMS), which coordinates with regional bodies when necessary to implement its mandate. National policy sees cultural heritage as a means for social inclusion and improvement of performance in four key indicators: health, crime, employment, and education. ${ }^{76} \mathrm{~A}$ recent feature of UK cultural

70 K. Chamberlain, K. Hausler, op. cit., p. 468.

71 E.g., the National Heritage Memorial Fund (NHMF), the Heritage Lottery Fund (HLF), the Art Fund, the V\&A Purchase and Grant Fund, and the National Fund for Acquisitions. Ibidem.

72 B. Boesch, op. cit., p. 89.

73 R. Maltezou, Greece Wants Parthenon Marbles Back, Tsipras Tells May, "Reuters", 26 June 2018, https:// www.reuters.com/article/us-britain-greece-marbles/greece-wants-parthenon-marbles-back-tsiprastells-may-idUSKBN1JM2T6 [accessed: 26.04.2019].

74 The Waverley Committee (1952) produced a report with three guiding criteria for determining whether cultural property should be exempted from export. These are: 1) Is the object so closely connected with our history or national life that its departure would be a misfortune?, 2) Is it of outstanding aesthetic importance?, 3) Is it of outstanding significance for the study of some particular branch of art, learning, or history? See K. Chamberlain, K. Hausler, op. cit., p. 472.

75 UK Government, Devolution of Powers to Scotland, Wales and Northern Ireland, https://www.gov.uk/guidance/devolution-of-powers-to-scotland-wales-and-northern-ireland [accessed: 26.04.2019].

76 E. Belfiore, Art as a Means of Alleviating Social Exclusion: Does It Really Work? A Critique of Instrumental Cultural Policies and Social Impact Studies in the UK, "International Journal of Cultural Policy" 2002, Vol. 8(1), p. 91. 
heritage policy is the creation of a more integrated system. The DCMS works at "arm's length" with the Arts Council of England (ACE), Regional Arts Boards, and other related bodies, granting the latter relative autonomy to allocate resources according to their own criteria and independent of political considerations, while also promoting cooperation. Public spending in the cultural heritage field is seen as an investment in alleviating socio-economic problems; this is a remnant of the Thatcherite era, where the arts needed to justify their presence against threats of expenditure cuts. ${ }^{77}$ The "defensive strategy" of emphasizing the arts sector's economic aspects and contributions is now the hallmark of an "enterprise culture", focusing on job creation, tourism, invisible earnings, and urban regeneration. ${ }^{78}$ The participation of local authorities in the UK cultural policy debate was crucial for the shift towards social considerations, rather than purely economic ones. Local funding has exceeded that of the central government since 1988, demonstrating a regional commitment to upholding culture due to its inherent value. ${ }^{79}$

The prevalence of recent policies dedicated to cultural heritage protection in the UK indicates that this is an area of fundamental public concern. In an increasingly diverse and globalized world, with London as a hub for urban migration, creative economy clusters, and a "melting pot", certain rural areas remain tethered to the notion of a quintessentially British identity, expressed most eloquently through the vote to leave the EU ("Brexit"). This tension has implications for governmental policies, which must balance national pride with the UK's status as an international power. At this juncture, prior to the finalization of Brexit negotiations, it is important to recognize the overarching principle of EU legal supremacy, which still continues in effect. Once the UK formally withdraws from the EU, the devolution Acts will likely serve as a template for the nation's distribution of legislative and executive powers in areas which are currently reserved or shared competences. ${ }^{80}$ Supporting competences, by contrast, will not be affected; this includes the areas of culture and tourism. ${ }^{81}$ The UK must then contemplate how it will develop its national identity without adherence to EU policies.

Furthermore, the role of technology in cultural development is crucial for policy making. The DCMS's Culture is Digital report indicates that the overlap between artistic/cultural creativity and technology is the economic "driving force" for

\footnotetext{
77 Ibidem, pp. 93-94.

78 Ibidem, p. 95.

79 Ibidem, pp. 96-97.

80 K. Hausler, FAQ: Cultural Heritage Post-Brexit, British Institute of International and Comparative Law, March 2018, https://www.biicl.org/brexitmaterials/culturalheritagepodcast [accessed: 26.04.2019]; also see: A. Page, The Implications of EU Withdrawal for the Devolution Settlement, prepared for the Culture, Tourism, Europe and External Relations Committee, 4 October 2016, http://www.parliament.scot/General\%20Documents/The_implications_of_EU_withdrawal_for_the_devolution_settlement.pdf [accessed: 26.04.2019].
}

81 Articles 6(c), 6(d), 167, 195 TFEU. See A. Page, op. cit., p. 19. 


\section{DEBUTS}

Claudia S. Quiñones Vilá

the UK's long-term prospects in light of Brexit. ${ }^{82}$ Although the culture and technology sectors are classified as "the ultimate power couple", the DCMS recognizes that further synergy is required to ensure that their respective interests align. ${ }^{83}$ The dual competitive advantage of these sectors has been honed since 2017 through the Government's ambitious Digital Strategy ${ }^{84}$ and Industrial Strategy, ${ }^{85}$ leading the country to be ranked 5th in the global innovation index and innovation leader on the Euro Innovation Scoreboard. ${ }^{86}$ Cultural organizations and practitioners contribute nearly a third of the creative industries' GVA, which is the fastest-growing sector in the UK. These industries cannot be viewed in isolation, but rather as an integral part of the UK's economic development through urban regeneration, providing skilled employment, and linking individuals across different communities. ${ }^{87}$ The devolved legislatures are also active partners in this development. ${ }^{88}$ Public and private stakeholders are thus very involved in the development of innovative strategies, demonstrating "a strong history of collaboration and successful partnership [...] [as] a way of life". ${ }^{89}$ This cooperation is crucial for ongoing and future cultural heritage protection and management.

\section{Analysis: Lessons Learned}

Despite the aforementioned States' cultural wealth, the UK has different preoccupations than Italy concerning its cultural heritage - economic considerations are at the forefront of policy-making and legislation..$^{90}$ Its impending exit from the EU has prompted debate and resulted in the development of cultural and technological synergies to promote the UK as a leading destination for the creative industries, in addition to tourism. Its common law system is additionally more flexible and allows for meaningful participation by private parties, whereas Italy's civil law system and constitutional mandates place the responsibility of cultural heritage preser-

82 DCMS, Culture is Digital, 7 March 2018, p. 4, https://www.gov.uk/government/publications/cultureis-digital [accessed: 26.04.2019].

83 Ibidem.

$84 \mathrm{https} / / / w w w . g o v . u k / g o v e r n m e n t /$ publications/uk-digital-strategy.

85 https://www.gov.uk/government/topical-events/the-uks-industrial-strategy.

86 Recently, the UK (particularly London) has raised more venture capital from tech investors than Germany, France, Spain, and Ireland combined. See DCMS, Culture is Digital, p. 8. See also, https://media.londonandpartners.com/news/2017-record-year-for-london-and-uk-tech-investment.

87 Between 2010-2016, creative industries increased by 45\%. DCMS, Culture is Digital, p. 8. See also, BOP Consulting, Mapping the Creative Industries: A Toolkit, British Council, London 2010, https://creativeconomy. britishcouncil.org/media/uploads/files/English_mapping_the_creative_industries_a_toolkit_2-2.pdf [accessed: 26.04.2019], p. 18.

88 Creative Scotland 10 Year Plan 2014-2024, Wales Prosperity for All.

89 DCMS, Culture is Digital, p. 15.

90 See D. Hesmondhalgh, A.C. Pratt, Cultural Industries and Cultural Policy, "International Journal of Cultural Policy" 2005, Vol. 11(1), pp. 1-14. 
vation primarily on the government. This means that public funds are considered the typical source for heritage management, instead of philanthropic donations or public-private partnerships. Allowing private stakeholders, including civilians, into the realm of cultural heritage management and preservation will result in a greater diversity of resources, both financial and creative. ${ }^{91}$ As such, the government in question will be able to adapt more quickly to challenges, exploit new technological tools in a smarter way, and reap economic benefits while ensuring that heritage remains protected for future generations.

In order to harness the full potential of cultural heritage, the EU and its Member States must look to policy outcomes at both the centralized and national levels. Effectiveness will be determined by successful implementation, which is in turn influenced by particular historical, social, political, and economic contexts. A "one size fits all" policy is therefore not advisable. Instead, the EU should focus on establishing a proper foundation for Member States to build upon.

The interplay between source and market countries provides fertile ground for discussions on cultural heritage as a common good, with various legal implications. ${ }^{92}$ To breach this divide, Pinton proposes that cultural heritage should have its own legal framework, outside of the traditional public/private goods dichotomy. This would reinforce democratic engagement while simultaneously cementing the idea of a common European identity, ensuring the sustainable safeguarding of cultural heritage for future generations. ${ }^{93}$ Pinton additionally points out that Article 15 of the Faro Convention asks States Parties to create a monitoring body through the Council of Europe, tasked with reviewing cultural heritage legislation, policies, and practices, and to maintain, develop, and contribute data to a shared information system, accessible to the public, to facilitate how States fulfil their commitments to the Convention and the principles espoused therein. ${ }^{94}$ The Faro Convention is therefore used as a template for cultural heritage cohesion by implementing responsibilities at the individual and collective levels and through democratic participation. ${ }^{95}$

This article supports the notion of cultural heritage as a "commons", belonging to both no one and everyone. Naturally, implementing a new and distinct legal framework would take time and deliberation, due to the pluralist nature of the EU, but ultimately such an effort would be beneficial for the sui generis nature of cultural heritage: "No matter their title, their collective fruition must be safeguarded, within

91 G. Palumbo, Privatization of State-Owned Cultural Heritage: A Critique of Recent Trends in Europe, in: N. Agnew, J. Bridgland (eds), Of the Past, for the Future: Integrating Archaeology and Conservation, The Getty Conservation Institute, Los Angeles 2006, p. 35-36.

92 F. Francioni, Public and Private in the International Protection of Global Cultural Goods, "The European Journal of International Law" 2012, Vol. 23(3), pp. 720-721.

93 S. Pinton, op. cit., pp. 321, 329.

94 Ibidem, p. 319.

95 G. Fairclough et al., The Faro Convention, a New Paradigm for Socially - and Culturally - Sustainable Heritage Action?, "Culture" 2014, Vol. 8, p. 11. 


\section{DEBUTS}

Claudia S. Quiñones Vilá

the limits of and according to the process of law". ${ }^{96}$ In other words, heritage items and sites will not be commodified and "reduced to the language of ownership" rather, preservation will be the new standard, within a "qualitative and functional relation" linking individuals and communities. ${ }^{97}$

At the moment, legal systems use the synchronization of public expenditures, tax incentives, hard and soft regulation, as well as the relationship between politicians and administrative officials to determine the scope and range of governmental interventions. Once this has been established, private parties can participate. The most important maxim is that "no single policy tool is likely to be successful on its own in giving effect to heritage policy; rather what matters is how different instruments are combined and which level of government is entitled to use them". ${ }^{98}$ Regulatory decisions are the primary element affecting the public-private mix in the heritage market. ${ }^{99}$ Providing direct and indirect public support for private investors, sponsors, and donors, both individuals and businesses, allows for the development of a wider variety of activities. Third-party research contributions are another source of information that can impact future legislation and concepts of heritage protection and management.

For instance, the Cultural Heritage Counts for Europe Consortium (CHCfE) prepared a 2015 report responding to the cultural policy shift in 2014, in order to fully present the benefits and impacts of cultural heritage for Europe. This report is significant on multiple levels and should be used as a reference for national and supranational policy-making. It determined that safeguarding cultural heritage acts as a "multiplier", with positive impacts further than what was originally intended, increasing the benefits and sustainability of the initial investment in terms of "upstream investment" and "downstream benefits"; these range from community participation and lifecycle prolongation to regional competitiveness and gross value added. ${ }^{100}$ Furthermore, the CHCfE issued five strategic recommendations. First, supporting evidence-based policy making through a holistic approach to collecting, managing, and interpreting data, as well as identifying, defining, and categorizing heritage impact indicators. Second, measuring the impact of cultural heritage by ensuring that stakeholders and operators engage in good practices and holistic

\footnotetext{
96 Ibidem, p. 329 (emphasis in the original).

97 Ibidem, p. 330.

98 I. Rizzo, Cultural Heritage: Economic Analysis and Public Policy, in: V.A. Ginsburgh, D. Throsby (eds.), Handbook of Economics of Art and Culture, Vol. 1, Elsevier, Amsterdam 2006, p. 1001; also see J.A.R. Nafziger, R.K. Paterson, Cultural Heritage Law, in: J.A.R. Nafziger, R.K. Paterson (eds.), op. cit., pp. 1-18.

99 I. Rizzo, op. cit., p. 1009.

100 CHCfE, Executive Summary of Cultural Heritage Counts for Europe Outcomes Report, July 2015, pp. 16-17, http://blogs.encatc.org/culturalheritagecountsforeurope/outcomes/ [accessed: 26.04.2019]; also see: M. Aymerich, Towards an Integrated Approach to Funding Cultural Heritage for Europe, 2015, http://www. europanostra.org/wp-content/uploads/2017/04/2015-FundingCulturalHeritage-ElB.pdf [accessed: 26.04.2019].
} 
impact assessments. Third, actively monitoring trends related to cultural heritage in order to inform policy makers at all levels. Fourth, sharing and disseminating available data to expand the same in scope and content, with a particular focus on regional and local participation. Fifth, maximizing impact through an integrated approach to heritage, participatory governance, and sustainable development. ${ }^{101}$ These recommendations correspond to qualitative and quantitative data streams and are a comprehensive way to tackle several pressing issues at the macro level.

While thorough, the $\mathrm{CHCfE}$ report does not include all related matters. In addition to incorporating private actors in heritage protection and management, the most relevant challenges for the cultural sector during the current 2014-2020 period include: the diversification of European cultural and creative sectors; the massive impact of digitalization on how culture is perceived, accessed, created, communicated, and disseminated; difficulties in accessing the funds needed to support cultural activities, maintain competitiveness, and internationalize; gathering and storing information and data for comparison; and building the relationships between research, innovation, science, education, and culture. ${ }^{102}$ Preparing a comprehensive report at the EU level would greatly improve access to interested groups and provide helpful data for future iterations of funded projects. The European Year of Cultural Heritage (EYCH) 2018 is also significant; it could spur the creation of a database with up-to-date and actualized information on how cultural heritage is perceived and accessed by different social groups across the EU. Additionally, Europe occupies $52 \%$ of the world's tourism market share, representing a major socio-economic activity with rapid growth requiring sustainable development to ensure that local identities and cultures are respected while encouraging employment. ${ }^{103}$

The key is for participating bodies to move forward pursuant to the evidence and data-based policies. As stated previously, the OMC is a beneficial way for Member States and the Union to share knowledge and expertise. In order to streamline the type of knowledge needed and facilitate recommendations, countries with similar heritage profiles should be grouped together. While they should still have access to the entirety of the information provided by all participating Member States, creating subgroups for States to brainstorm over common problems could lead to creative solutions. With proper planning, heritage can act as a "driver" of development by limiting the negative effects of globalization and providing for social cohesion, well-being, and understanding between different communities. ${ }^{104}$ "Smart cities"

\footnotetext{
101 CHCfE, op. cit., p. 33.

102 S. Zabeo, D. Pellizzon, Cultural Heritage in the Frame of European Funding Programmes: Challenges and Opportunities, in: S. Pinton, L. Zagato (eds.), Cultural Heritage: Scenarios 2015-2017, Ca' Foscari - Digital Publishing, Venice 2017, pp. 70-71.

103 European Parliament, Resolution of 29 October 2015 on new challenges and concepts for the promotion of tourism in Europe (2014/2241(INI)), P8_TA(2015)0391.

104 J. Hosagrahar et al., op. cit., pp. 8-9.
} 


\section{DEBUTS}

Claudia S. Quiñones Vilá

such as London, which integrate the creative industries with culturally diverse participants and technological development, are at the forefront of this type of urbanization. ${ }^{105}$ It is more inclusive, promotes peace, and creates opportunities for employment and the alleviation of poverty. ${ }^{106}$ This view represents "the need to adopt 'people centred approaches to evaluation' that can address the outcomes, rather than the outputs, of policy initiatives". 107 The relevance of decision-making and underlying motives also come into play, as policies are not created in a vacuum. ${ }^{108}$

A holistic approach is therefore crucial in order to fully integrate and benefit from the multifaceted qualities of national cultural heritage. For instance, the UK announced its intention to secure a groundbreaking sector deal for the tourism industry. ${ }^{109}$ This is the result of the DCMS collecting various kinds of data from private and public shareholders to identify policy gaps and make feasible suggestions for improvement. ${ }^{110}$ Additionally, the overlap between the DCMS publications and the government's Digital and Industrial Strategies ensure a cohesive framework, capable of addressing problems as they occur. With its many heritage sites, as well as tangible and intangible forms of heritage, Italy would certainly benefit from a similar approach. However, as pointed out above, the long-standing political, administrative, and regional divides prevent the seamless implementation of cross-sectoral initiatives.

Partnerships are an effective way to obtain and disseminate greater amounts of input, leading to evidence-driven regulatory and policy outcomes, "including increased capacity, sharing skills and knowledge, increasing access to collections, reaching new audiences and accessing cutting edge research and new knowledge". ${ }^{111}$ The main issue is the effective implementation - or lack thereof - of cultural policies tailored with a full understanding of the respective States' needs and cultural contexts. In the case of Italy, conservation of monuments and objects in the care of public institutions requires creative solutions to compensate for the lack of funding. Regional governments can help bridge this gap through partnerships with private entities that go beyond standard offers of sponsorship. For ex-

105 See: C. Rocks, London's Creative Industries - 2017 Update, Greater London Authority, July 2017, https://www.london.gov.uk/sites/default/files/working_paper_89-creative-industries-2017.pdf [accessed: 26.04.2019]; also see: A. Pratt, Creative Cities: Tensions within and between Social, Cultural and Economic Development. A Critical Reading of the UK Experience, "City, Culture and Society" 2010, Vol. 1(1), pp. 13-20.

106 J. Hosagrahar et al., op. cit., p. 10.

107 E. Belfiore, op. cit., p. 98 (emphasis in the original).

108 I. Rizzo, op. cit., p. 1005.

109 DCMS, Government Signals Intention to Secure Tourism Sector Deal, 27 November 2018, https://www. gov.uk/government/news/government-signals-intention-to-secure-tourism-sector-deal [accessed: 26.04.2019].

110 See DCMS, The Culture White Paper, 23 March 2016, https://www.gov.uk/government/publications/ culture-white-paper [accessed: 26.04.2019].

111 DCMS, Culture is Digital, p. 67. 
ample, in late March 2019 the city of Rome announced that it would be partnering with Gucci to restore the Tarpeian Rock, and will use the Capitoline Museums as the location for its 2020 fashion show. ${ }^{112}$ This will not only ensure financial capital, but also provide positive exposure for both parties, which they can continue to develop in the future.

In addition to lateral cooperation, bottom-up alliances are also productive, as "local knowledge is shared knowledge". ${ }^{113}$ Regional governments are typically more qualified to identify which local traditions and forms of cultural heritage require preservation, and can pinpoint the resources required. Devolution provides them with greater autonomy while ensuring that national policy goals are still met. However, there are both benefits and disadvantages to devolution in cultural matters. On the positive side,

sub-national tiers of government will be able to interpret the need for conservation better than the central government, given that the link between heritage and citizens is closest in the community in which the heritage is located. This issue is relevant in multicultural societies, where local governments can be considered more suitable for providing services for ethnic groups and for promoting the participation of minorities. ${ }^{114}$

On the negative side, "[p]olicies tend to be easier to promote if decisions are taken by one decision maker [...] while transaction costs will be higher if an agreement has to be reached between different layers of government, each with different responsibilities" ${ }^{115}$ Successful devolution therefore appears to depend on two circumstances: First, whether the population is diverse; and second, whether the relationship between the governmental bodies is contentious or cooperative. This will vary among Member States according to their political subdivisions.

Finally, heritage is sustainable to the extent that it has the capacity to adapt to change through creative transformation and constantly continues to develop. ${ }^{116}$ While "[i]nter-cultural dialogue, including inter-religious dialogue, can help promote the building of fair, peaceful and inclusive societies that value cultural diversity and respect [...] human rights", ${ }^{117}$ this is easier said than done. Persistent racial and reli-

112 N. Squires, Fashion House Gucci to Sponsor Restoration of Roman Cliff from Which Traitors Were Flung to Their Deaths, "The Telegraph", 16 March 2019, https://www.telegraph.co.uk/news/2019/03/16/fashionhouse-gucci-sponsor-restoration-roman-cliff-traitors/ [accessed: 26.04.2019].

113 A. Sieber, Local Knowledge as a Research Tool to Save Cultural Heritage, Council of Europe, 25 July 2018 , p. 2, https://rm.coe.int/faro-convention-topical-series-article-4-local-knowledge-as-research-t/16808 aa972 [accessed: 26.04 .2019$]$.

114 I. Rizzo, op. cit., p. 1006.

115 Ibidem, p. 1007.

116 C. Holtorf, Embracing Change: How Cultural Resilience is Increased Through Cultural Heritage, "World Archaeology" 2018, p. 5.

117 Towards an EU strategy..., p. 10. 


\section{DEBUTS}

Claudia S. Quiñones Vilá

gious differences present a barrier to the full harmonization of cultural views. Despite globalization, local input - particularly regarding cultural heritage - cannot be ignored, as it is "a reality which is [an] expression of a powerful collective identity and of potential strategies of development". ${ }^{118}$ Both aspects must be considered in tandem, not as mutually exclusive. For instance, the UK has been subject to deadly terrorist attacks in recent years despite its cultural diversity, indicating that feelings of alienation continue to drive recruitment. The reinforcement of social cohesion "by fostering a sense of shared responsibility towards the places in which people live"119 is a critical factor in cultural heritage protection. Building trust and respect are essential for participatory governance, in addition to mediating different social components and involving local stakeholders to achieve the end goal of cultural heritage engagement. ${ }^{120}$

The combination of migration and rapid urbanization and globalization can result in "a culture that is indifferent to long-term sustainability and to the common interest". ${ }^{121}$ Cultural heritage preservation combats such pressures via social cohesion. The notion of "place" as determinative to urban and cultural regeneration must be explored within the context of terrorism and other anti-social behaviours. Globalization "raises a growing demand for character and identity [...] Place-making assumes a key role in the urbanization processes to satisfy the need for identity". ${ }^{122}$ There remain gaps in minority ethnic groups' access to culture, and they are consistently under-represented, skewing engagement towards higher socioeconomic groups. ${ }^{123}$ By utilizing culture to provide these groups with greater access to national services, a positive link is created between members of insular communities and society at large. Culture helps to create a safe space, both metaphorically and physically, working within the liminal boundaries of population clusters. The result is a culture - and nation - that is resilient, adaptable, and thriving.

\section{Recommendations}

As a result of my investigation, the following recommendations should serve as a guide for ongoing and future cultural heritage policy in the EU:

- Combine a holistic approach with evidence-based policy making when formulating and implementing public policy and legislation. This includes tak-

\footnotetext{
118 E. Moustaira, op. cit., p. 4.

119 Article 8(c) of the Faro Convention.

120 C. Gustafsson, J. Stanojev, Recommendations Forum "European Year of Cultural Heritage 2018: International Perspectives", Cultural Diplomacy Platform, 31 May 2018, p. 12, https://www.cultureinexternalrelations.eu/cier-data/uploads/2018/09/EYCH-2018-International-Perspectives.pdf [accessed: 26.04.2019].

121 J. Hosagrahar et al., op. cit., p. 15.

122 Ibidem, p. 14.

123 DCMS, Culture is Digital, p. 21.
} 
ing into account States' social, economic, political, and historical contexts to create tailored approaches;

- Utilize the CHCfE report as a model for heritage impact assessment and integrated policy making;

- Make a greater effort to include regional administrative and legislative bodies, plus citizens' groups;

- Make information readily accessible online and promote diverse participation as desirable;

- Recommend public-private partnerships to compensate for the lack of available government funds and to engage in constructive relationship-building and problem-solving;

- Form geographical/cultural subgroups within the OMC to better identify and resolve heritage management problems;

- Create a comprehensive report on funding opportunities and requirements for cultural and heritage projects in the $\mathrm{EU}$, and streamline available informational resources to make it more accessible for the public;

- Utilize digital and new media tools to reach and engage with a broader audience, not only in traditional settings (e.g., museums), but also when promoting local activities;

- Continue to engage the youth population through arts education, imparting the significance of cultural heritage for quality of life and ensuring future safeguarding of this resource;

- Organize community activities, particularly in regions with prior cultural activity deficits or a high degree of cultural heterogeneity, in order to create a feeling of belonging within the larger national and international communities;

- Develop the creative and tourism industries while integrating residential concerns and sustainable development principles;

- Create incentives for private parties to participate in heritage management, including through tax breaks and sponsorship opportunities;

- Consider the implementation of a distinct legal framework for cultural heritage, utilizing the Faro Convention as a guide;

- Harness the phenomenon of globalization to increase diversity and involve more stakeholders in democratic decision-making processes.

\section{Conclusions}

Cultural heritage protection and promotion is a pressing issue for the EU and Member States, given its moral, aesthetic, and economic connotations, and in light of national and international expansion across tangible as well as digital borders. Nevertheless, concrete problems remain. For instance, countries which exhibit strong regional identities as opposed to national identities, such as Italy, cause fissures 


\section{DEBUTS}

Claudia S. Quiñones Vilá

in policy-making. This leads to the uneven application of legislation and a lack of targeted solutions to local problems due, in part, to national governments' limited budgets and also to a resistance to public-private partnerships. It has become increasingly clear that while culture is a public concern, the key to heritage protection and evolution lies with the private sector.

In terms of approaches to cultural heritage preservation, these can be divided into two camps: the moral/aesthetic (Italy) and the capitalist/economic (UK). The economic dimension has proved more successful in integrating various policy measures towards a single goal, traversing sectors and engaging stakeholders in the public and private fields. Nonetheless, the moral dimension should not be abandoned completely. Rather, it should be utilized as a foundation for policies to build upon, conscious of the need to modernize and interact with technology as well as with other global actors. Member States can no longer rely solely on internal tourism or their individual budgets to reap the full advantages of cultural heritage. Instituting public-private partnerships, engaging in a holistic approach, utilizing creative means of outsourcing, and stimulating citizen engagement are the hallmarks of a modern and effective cultural protection policy. As interest in cultural heritage grows, so too will the diversity of those involved, who in turn will provide newer and better ways of problem solving. The EU and Member States have already demonstrated their commitment to safeguarding cultural heritage; the next step is to ensure that forward-looking cultural policies continue to be implemented effectively.

\section{References}

Ahmad Y., The Scope and Definitions of Heritage: From Tangible to Intangible, "International Journal of Heritage Studies" 2006, Vol. 12(3).

Amaro S., Italy's Anti-establishment Government Hopes the Rules Change in Its Favor Next May, "CNBC", 9 October 2018, https://www.cnbc.com/2018/10/09/italys-populist-government-hopes-the-rules-change-in-its-favor.html [accessed: 26.04.2019].

Aymerich M., Towards an Integrated Approach to Funding Cultural Heritage for Europe, 2015, http://www.europanostra.org/wp-content/uploads/2017/04/2015-FundingCulturalHeritage-EIB.pdf [accessed: 26.04.2019].

Belfiore E., Art as a Means of Alleviating Social Exclusion: Does It Really Work? A Critique of Instrumental Cultural Policies and Social Impact Studies in the UK, "International Journal of Cultural Policy" 2002, Vol. 8(1).

Benedikter R., Privatisation of Italian Cultural Heritage, "International Journal of Heritage Studies" 2004, Vol. 10(4).

Bodo C., Bodo S., Italy. Historical Perspective: Cultural Policies and Instruments, "Compendium: Cultural Policies and Trends", 5 July 2016, https://www.culturalpolicies.net/web/italy. php [accessed: 26.04.2019].

Boesch B., The Art Collecting Legal Handbook, Thomson Reuters, London 2013.

BOP Consulting, Mapping the Creative Industries: A Toolkit, British Council, London 2010, https://creativeconomy.britishcouncil.org/media/uploads/files/English_mapping_ the_creative_industries_a_toolkit_2-2.pdf [accessed: 26.04.2019]. 
Butcher J., Cultural Politics, Cultural Policy and Cultural Tourism, in: M.K. Smith, M. Robinson (eds.), Cultural Tourism in a Changing World: Politics, Participation and (Re)presentation, Channel View Publications, Bristol 2006.

Chamberlain K., Hausler K., United Kingdom, in: J.A.R. Nafziger, R.K. Paterson (eds.), Handbook on the Law of Cultural Heritage and International Trade, Edward Elgar Publishing, Cheltenham 2014.

Codice dei beni culturali e del paesaggio [Landscape and Cultural Heritage Code], 22 January 2004, Gazzetta Ufficiale Serie Generale No. 45.

Commission of the European Communities, Communication from the Commission to the European Parliament, the Council, the European Economic and Social Committee and the Committee of the Regions on a European agenda for culture in a globalizing world, 10 May 2007, COM (2007) 242 final.

Constitution of the Italian Republic, https://www.senato.it/documenti/repository/istituzione/costituzione_inglese.pdf [accessed: 26.04.2019].

Constitutional Law 3 of 18 October 2001, Gazzetta Ufficiale Serie Generale No. 248.

Convention on the Means of Prohibiting and Preventing the Illicit Import, Export and Transfer of Ownership of Cultural Property, 14 November 1970, 823 UNTS 231.

Council of Europe Convention on Offences relating to Cultural Property, 19 May 2017, CETS 221.

Council of Europe Framework Convention on the Value of Cultural Heritage for Society, 27 October 2005, CETS 199.

Council of Europe, Compendium Short Profile: Italy, https://www.culturalpolicies.net/web/ files/308/en/Italy.pdf [accessed: 26.04.2019].

Council of the European Union, Conclusions of the Council and of the Representatives of the Governments of the Member States, meeting within the Council, on a Work Plan for Culture (2015-2018), OJ C 463, 23.12.2014, p. 4.

Council of the European Union, Council conclusions of 21 May 2014 on cultural heritage as a strategic resource for a sustainable Europe, OJ C 183, 14.06.2014, p. 36.

Council of the European Union, Council conclusions of 26 November 2012 on Cultural Governance, OJ C 393, 19.12.2012, p. 8.

Council of the European Union, Council conclusions of 6 December on the Work Plan for Culture 2019-2022, OJ C 460/10, 21.12.2018, p. 12.

Council of the European Union, The Rome Declaration: Declaration of the leaders of 27 member states and of the European Council, the European Parliament and the European Commission, Statements and Remarks 149/17, 25 March 2017, https://www.consilium.europa.eu/ en/press/press-releases/2017/03/25/rome-declaration/pdf [accessed: 26.04.2019].

Cultural Heritage Counts for Europe, Executive Summary of Cultural Heritage Counts for Europe Outcomes Report, July 2015, http://blogs.encatc.org/culturalheritagecountsforeurope/outcomes/ [accessed: 26.04.2019].

Day M., Italy's Cultural Heritage at Risk Amid Neglect and Bad Management - With Private Sponsors Brought in to Help Protect Iconic Landmarks, "The Independent", 17 May 2015, https://www.independent.co.uk/news/world/europe/italys-cultural-heritage-at-riskamid-neglect-and-bad-management-with-private-sponsors-brought-in-to-10256659. html [accessed: 26.04.2019]. 


\section{DEBUTS}

Claudia S. Quiñones Vilá

Decision (EU) 2017/864 of the European Parliament and of the Council of 17 May 2017 on a European Year of Cultural Heritage (2018), OJ L 131, 20.05.2017, p. 1.

Department for Digital, Culture, Media \& Sport, Culture is Digital, 7 March 2018, https:// www.gov.uk/government/publications/culture-is-digital [accessed: 26.04.2019].

Department for Digital, Culture, Media \& Sport, Government Signals Intention to Secure Tourism Sector Deal, 27 November 2018, https://www.gov.uk/government/news/government-signals-intention-to-secure-tourism-sector-deal [accessed: 26.04.2019].

Department for Digital, Culture, Media \& Sport, The Culture White Paper, 23 March 2016, https://www.gov.uk/government/publications/culture-white-paper [accessed: 26.04.2019].

European Commission, Communication from the Commission to the European Parliament, the Council, the European Economic and Social Committee and the Committee of the Regions on a European agenda for culture in a globalizing world, 10 May 2007, COM(2007) 242 final.

European Commission, Communication from the Commission to the European Parliament, the Council, the European Economic and Social Committee and the Committee of the Regions: Towards an integrated approach to cultural heritage for Europe, 22 July 2014, $\operatorname{COM}(2014) 477$ final.

European Commission, Communication from the Commission to the European Parliament, the European Council, the Council, the European Economic and Social Committee and the Committee of the Regions: A New European Agenda for Culture, 22 May 2018, COM(2018) 267 final.

European Commission, Communication on a European agenda for culture in a globalizing world, 10 May 2007, COM(2007) 242 final.

European Commission, Joint Communication to the European Parliament and the Council: Towards an EU strategy for international cultural relations, 8 June 2016, JOIN(2016) 29 final.

European Commission, Mapping of Cultural Heritage Actions in European Union Policies, Programmes And Activities, 2014 (latest update: August 2017, http://ec.europa.eu/assets/ eac/culture/library/reports/2014-heritage-mapping_en.pdf [accessed: 26.04.2019].

European Commission, Proposal for a Decision of the European Parliament and of the Council on a European Year of Cultural Heritage, 30 August 2016, COM(2016) 543 final, 2016/0259 (COD).

European Commission, Strategic framework - European Agenda for Culture, https://ec.europa. eu/culture/policy/strategic-framework_en [accessed: 26.04.2019].

European Parliament, Committee on Culture, Youth, Education, the Media and Sport, Report on cultural cooperation in the European Union (2000/2323(INI)), 16 July 2001, A5-0281/2001.

European Parliament, Resolution of 29 October 2015 on new challenges and concepts for the promotion of tourism in Europe (2014/2241(INI)), P8_TA(2015)0391.

Fairclough G. et al., The Faro Convention, a New Paradigm for Socially - and Culturally - Sustainable Heritage Action?, "Culture" 2014, Vol. 8.

Forbes A., Italy Announces Sweeping Cultural Reforms, "Artnet News", 21 July 2014, https:// news.artnet.com/art-world/italy-announces-sweeping-cultural-reforms-64457 [accessed: 26.04.2019].

Forte P., I nuovi musei statali: un primo passo nella giusta direzione, "Aedon" 2015, Vol. 1 , http:// www.aedon.mulino.it/archivio/2015/1/forte.htm [accessed: 24.04.2019]. 
Francioni F., Public and Private in the International Protection of Global Cultural Goods, "The European Journal of International Law" 2012, Vol. 23(3).

Frigo M., Italy, in: J.A.R. Nafziger, R.K. Paterson (eds.), Handbook on the Law of Cultural Heritage and International Trade, Edward Elgar Publishing, Cheltenham 2014.

Gustafsson C., Stanojev J., Recommendations Forum "European Year of Cultural Heritage 2018: International Perspectives", Cultural Diplomacy Platform, 31 May 2018, https://www. cultureinexternalrelations.eu/cier-data/uploads/2018/09/EYCH-2018-International-Perspectives.pdf [accessed: 26.04.2019].

Hausler K., FAQ: Cultural Heritage Post-Brexit, British Institute of International and Comparative Law, March 2018, https://www.biicl.org/brexitmaterials/culturalheritagepodcast [accessed: 26.04.2019].

Hesmondhalgh D., Pratt A.C., Cultural Industries and Cultural Policy, "International Journal of Cultural Policy" 2005, Vol. 11(1).

Holtorf C., Embracing Change: How Cultural Resilience is Increased Through Cultural Heritage, "World Archaeology" 2018.

Hosagrahar J. et al., Heritage, the UN Sustainable Development Goals, and the New Urban Agenda, "ICOMOS Concept Note on Housing and Sustainable Urban Development (HABITAT III)", 15 February 2016, https://www.usicomos.org/mainsite/wp-content/ uploads/2016/05/Final-Concept-Note.pdf [accessed: 26.04.2019].

Kisić V., Governing Heritage Dissonance. Promises and Realities of Selected Cultural Policies, European Cultural Foundation, Amsterdam 2016, https://www.europanostra.org/ wp-content/uploads/2017/01/Governing_Heritage_Dissonance.pdf [accessed: 26.04.2019].

Law 112 of 15 June 2002, Gazzetta Ufficiale Serie Generale No. 139.

Law 213 of 7 June 1999, Gazzetta Ufficiale Serie Generale No. 153.

Maltezou R., Greece Wants Parthenon Marbles Back, Tsipras Tells May, "Reuters", 26 June 2018, https://www.reuters.com/article/us-britain-greece-marbles/greece-wantsparthenon-marbles-back-tsipras-tells-may-idUSKBN1JM2T6 [accessed: 26.04.2019].

Moustaira E., Art Collections, Private and Public: A Comparative Legal Study, Springer, Cham 2015.

Nafziger J.A.R., Paterson R.K., Cultural Heritage Law, in: J.A.R. Nafziger, R.K. Paterson (eds.), Handbook on the Law of Cultural Heritage and International Trade, Edward Elgar Publishing, Cheltenham 2014.

Page A., The Implications of EU Withdrawal for the Devolution Settlement, prepared for the Culture, Tourism, Europe and External Relations Committee, 4 October 2016, http:// www.parliament.scot/General\%20Documents/The_implications_of_EU_withdrawal_for_the_devolution_settlement.pdf [accessed: 26.04.2019].

Palumbo G., Privatization of State-Owned Cultural Heritage: A Critique of Recent Trends in Europe, in: N. Agnew, J. Bridgland (eds), Of the Past, for the Future: Integrating Archaeology and Conservation, The Getty Conservation Institute, Los Angeles 2006.

Pasikowska-Schnass M., Cultural Heritage in EU Policies, European Parliamentary Research Service, June 2018, http://www.europarl.europa.eu/RegData/etudes/BRIE/2018/ 621876/EPRS_BRI(2018)621876_EN.pdf [accessed: 26.04.2019].

Pinton S., The Faro Convention, the Legal European Environment and the Challenge of Commons in Cultural Heritage, in: S. Pinton, L. Zagato (eds.), Cultural Heritage: Scenarios 2015-2017, Ca' Foscari - Digital Publishing, Venice 2017. 


\section{DEBUTS}

Claudia S. Quiñones Vilá

Pratt A., Creative Cities: Tensions within and between Social, Cultural and Economic Development. A Critical Reading of the UK Experience, "City, Culture and Society" 2010, Vol. 1(1).

Presidential Decree 616 of 24 July 1977, Gazzetta Ufficiale Serie Generale No. 234.

Protocol No. 2 to the Treaty on the Functioning of the European Union on the application of the principles of subsidiarity and proportionality (consolidated version), OJ C 326, 26.10.2012, p. 206.

Rizzo I., Cultural Heritage: Economic Analysis and Public Policy, in: V.A. Ginsburgh, D. Throsby (eds.), Handbook of Economics of Art and Culture, Vol. 1, Elsevier, Amsterdam 2006.

Rocks C., London's Creative Industries - 2017 Update, Greater London Authority, July 2017, https://www.london.gov.uk/sites/default/files/working_paper_89-creative-industries-2017.pdf [accessed: 26.04.2019].

Scammell R., Saving Italy's Cultural Heritage by Modern Means, "The Guardian", 19 March 2015, https://www.theguardian.com/world/2015/mar/19/saving-italys-cultural-heritage-by-modern-means [accessed: 26.04.2019].

Scammell R., The New British Caretaker of Italian Culture, "The Observer", 26 June 2016, https://www.theguardian.com/culture/2016/jun/25/james-bradburne-british-museum-director-artistic-revolution-milan [accessed: 26.04.2019].

Sieber A., Local Knowledge as a Research Tool to Save Cultural Heritage, Council of Europe, 25 July 2018, https://rm.coe.int/faro-convention-topical-series-article-4-localknowledge-as-research-t/16808aa972 [accessed: 26.04.2019].

Squires N., Fashion House Gucci to Sponsor Restoration of Roman Cliff from Which Traitors Were Flung to Their Deaths, "The Telegraph", 16 March 2019, https://www.telegraph.co.uk/ news/2019/03/16/fashion-house-gucci-sponsor-restoration-roman-cliff-traitors/ [accessed: 26.04.2019].

Treaty on European Union (consolidated version), OJ C 326, 26.10.2012, p. 13.

Treaty on the Functioning of the European Union (consolidated version), OJ C 326, 26.10.2012, p. 47.

UNIDROIT Convention on Stolen or Illegally Exported Cultural Objects, 24 June 1995, 34 ILM 1322.

Ventura C., Cassalia G., Della Spina L., New Models of Public-Private Partnership in Cultural Heritage Sector: Sponsorships between Models and Traps, "Procedia - Social and Behavioral Sciences" 2016, Vol. 223.

Vogt A., Italy's Populist Government Brings In New Laws to Crack Down on Artefact Trafficking Amidst Nationalist Swell, "The Telegraph", 4 November 2018, https://www.telegraph. co.uk/news/2018/11/04/italys-populist-government-brings-new-laws-crack-artefact-trafficking/ [accessed: 26.04.2019].

Wecker M., Looted Vessels Returned at Event Marking 15 Years of US-Italy Art Crime Fighting Co-operation, "The Art Newspaper", 6 November 2018, https://www.theartnewspaper.com/news/looted-vessels-returned-at-event-marking-15-years-of-us-italy-artcrime-fighting-co-operation [accessed: 26.04.2019].

Woodhouse A., Politi J., Populist Five Star Movement Secures 32\% of Vote in Italian Election, "Financial Times", 5 March 2018, https://www.ft.com/content/ecd89a82-2045-11e8a895-1ba1f72c2c11 [accessed: 26.04.2019].

Zabeo S., Pellizzon D., Cultural Heritage in the Frame of European Funding Programmes: Challenges and Opportunities, in: S. Pinton, L. Zagato (eds.), Cultural Heritage: Scenarios 2015-2017, Ca' Foscari - Digital Publishing, Venice 2017. 